\title{
エネルギー便益の統合化によるバイオ燃料生産の評価法の提案 宇都宮市の自動車走行距離と暖房熱量を対象とした試算結果
}

\author{
野口良造*1)・小山瑞樹2)
}

\author{
1）筑波大学大学院生命環境科学研究科干305-8572 茨城県つくば市天王台1-1-1 \\ 2）宇都宮大学大学院農学研究科 $=321-8505$ 栃木県宇都宮市峰町350
}

\begin{abstract}
要旨
バイオ燃料生産のエネルギー収支比による評価の問題点を補うために，シグモイド関数を用いたエネルギー便 益の充足度関数, および複数の便益の統合化を行う多属性効用関数にもとづいて, 統合便益比を提案した. また, 宇都宮市の総自動車の年間走行距離と総世帯の年間暖房熱量についてのエネルギー便益を充足度関数で表し, 宇 都宮市の耕作放棄地を水田戋場として利用し, 生産された稲をバイオマス資源とする, 二種類のバイオ燃料生産 について，エネルギ一収支比と統合便益比の試算と考察を行った，その結果，バイオ燃料生産の評価を，熱量換 算だけでなく, 複数のエネルギー便益の収支の観点から評価することによって, エネルギー収支比が 1 より少な い場合でも, 統合便益比が 1 を上回る場合が認められた。 また, エネルギー収支比に統合便益比を加えた評価に よって，エネルギー収支比だけでなく，社会全体のエネルギ一便益の増減の観点から，意思決定支援の可能性が 示された.
\end{abstract}

キーワード

便益, バイオ燃料, エネルギー収支比, 充足度

\section{はじめに}

石油資源の枯渇, 地球温暖化対策としての $\mathrm{CO}_{2}$ 排出量の 削減義務, 農業・農村振興を背景として, バイオ燃料生産 が世界中で行われている（経済産業省 2006）（バイオマス・ ニッポン総合戦略推進会議 2007). エネルギー効率からみ たバイオ燃料生産の評価法として, 投入エネルギー量に対 する生産エネルギー量の熱量換算（たとえばジュール $[\mathbf{J}]$ ) の比である，エネルギ一収支比（Energy Payback Ratio， あ るいは Energy Profit Ratio など）が,一般的に良く用いられ ている (CIGR 1999, 野村総合研究所 2007, Pimentel 2007).

エネルギー収支比によるエネルギー効率の評価では, 投 入エネルギー量と生産エネルギー量が同じ熱量であればエ ネルギー収支比が 1 となる. また, エネルギー収支比が 1 を超えて大きい值であるほどバイオ燃料生産のエネルギー 効率が良く, エネルギー収支比が 1 未満の場合はエネルギー

* Corresponding Author

E-mail: noguchi.ryozo.gm@u.tsukuba.ac.jp
効率が悪くなる. このように, エネルギー収支比は, エネ ルギー効率を測る上で分かりやすい指標ではあるが, 熱量 という一つの単位で評価を行うために, エネルギーの質の 違いを表すエクセルギー（山地 2006）や，エネルギーを利 用して得られる便益（以下「エネルギー便益」）（溝口ら 2008）などが反映されていない. よって, エネルギー収支 比によるバイオ燃料生産の評価には, 課題が残されている と考えられる.

本論文では, バイオ燃料生産のエネルギー収支比による 評価の問題点を補うために, シグモイド関数を用いたエネ ルギー便益の充足度関数, および複数の便益の統合化を行 う多属性効用関数にもとづいて, 統合便益比を提案した. また, 宇都宮市の総自動車の年間走行距離と総世帯の年間 暖房熱量についてのエネルギー便益を, 充足度関数で表し た.さらに, 宇都宮市の耕作放棄地を水田戋場として利用 し, 生産された稲をバイオマス資源とする, 二種類のバイ オ燃料生産について, エネルギ一収支比と統合便益比の試 算と考察を行った. 


\section{評価法の提案}

\section{エネルギー収支比の問題点}

バイオ燃料生産は, たとえば, バイオマス生産戋場やバ イオ燃料のプラントなどにおいて, 軽油, 灯油, 電気, 蒸 気, バイオエタノール (以下「エタノール」), 余熱といっ た多様な形態のエネルギーを取り扱う（佐賀 2007, 野口・ 齋藤 2008). バイオ燃料生産に関わるエネルギーの種類を $n$ とし, バイオマス生産围場（栽培, 収集, 運搬, 調製を含 む）やバイオマスプラントなどへ投入されるエネルギー （量）を $\mathrm{E}(n \times 1)$ とする. また, 単位面積当たりのバイオ マス生産量を一定とし, 生産されたエネルギー（量） $\mathrm{E}^{\prime}(n$ ×1）は，取り扱うバイオマス量に比例するとする，なお， 本論文では, 取り扱うエネルギーの種類 $n$ とし, たとえば, バイオ燃料生産体系で用いられる全てのエネルギーの種類 を, 軽油, ガソリン, 灯油, 電気, 蒸気, エタノールの六 種類の場合, $n=6$ として取り扱う. 全く取り扱わない場合 は, $\mathrm{E} や \mathrm{E}^{\prime}$ にかかる係数行列の対応の要素を「0」として 計算を行うこととした，また，単位は，軽油 $[\mathrm{L}]$, ガソリ ン $[\mathrm{L}]$, 灯油 $[\mathrm{L}]$, 電気 $[\mathrm{kWh}]$, 蒸気 $[\mathrm{MJ}]$, エタノール [L]とした.

このとき, バイオマス生産围場面積 $S$, 単位面積当たり に投入されるエネルギー (量) $\mathrm{D}(n \times 1)$, 単位面積当たり から最終的に得られるエネルギー（量） $\mathrm{D}^{\prime}(n \times 1)$ ，それぞ れのエネルギー量を熱量（ジュール「J」など）へ変換する 行列 $\mathrm{U}(1 \times n)$ を用いると, バイオ燃料生産におけるエネ ルギー収支比 $\left(E_{P R}\right)$ は,

$$
E_{P R}=\frac{\mathrm{UE}^{\prime}}{\mathrm{UE}}=\frac{\mathrm{UD}^{\prime} S}{\mathrm{UDS}}=\frac{\mathrm{UD}^{\prime}}{\mathrm{UD}}
$$

と表すことができる. しかし, エネルギーが周囲と平衡状 態に達するまでの最大仕事量であるエクセルギーの観点か らみれば，バイオ燃料生産に関する多様なエネルギーは, それぞれのエネルギーとの間に，質的差異が存在すること になる (山地 2006)。 そのため, 輸送用燃料として利用を想 定したバイオ燃料生産において，エネルギー収支比が 1 を 超えているにも関わらず, 全体のエクセルギー量が減少し， 投入したエネルギーを用いた走行距離よりも，生産された エネルギーを用いた走行距離が減少する場合が想定され る. また，暖房のための灯油燃焼とヒートポンプ利用とで は, 熱エネルギー効率に違いがあるように, 同じエネルギー 量でも, 技術の違いによって得られる便益量は変化する(省 エネルギーセンター2004)。したがって, バイオ燃料生産の 導入によって, 社会的な便益量が増加するかは, 式 (1) で 表されるエネルギー収支比のみでは十分な評価ができない と考えられる.

\section{便益比の問題点}

公共事業などによる社会貢献の有効性を判断するための 評価法として, 便益という一元的な単位に置き換えた費用
便益分析 (cost benefit analysis) があり（穴口ら 1999），バ イオ燃料生産の評価への重要性が指摘されている (Dalgaard et al. 2006). 本論文では, 費用便益分析のなかで の便益に着目し, 便益の量で, エネルギー利用の効率の比 較を行うこととした。 つまり，エネルギー収支比のエネル ギー量に代わる便益量の比によって, エネルギー収支比よ りも, バイオ燃料生産の導入の是非を数量的に判断できる と仮定した.

そこで, 移動, 空調, 照明といったエネルギー便益の数 を $m$ とするとき, 式（1）にならって，投入エネルギーが 有する便益量 $\mathrm{B}(m \times 1)$ と, 産出エネルギーが有する便益 量 $\mathrm{B}^{\prime}(m \times 1)$ の比である便益比 $B_{P R}$ は, それぞれのエネル ギーから得られる便益量を求めることができる便益変換係 数 C $(m \times n)$ を用いて,

$$
B_{P R}=\frac{\mathrm{B}^{\prime}}{\mathrm{B}}=\frac{\mathrm{CD}^{\prime} S}{\mathrm{CDS}}=\frac{\mathrm{CD}^{\prime}}{\mathrm{CD}}
$$

と表すことができる.

たとえば， ある面積 $S$ でのバイオマス生産で使用された エネルギーを軽油と電気の二種類とし, 軽油が $10 \mathrm{~L}$, 電気 が $100 \mathrm{kWh}$ 使用された場合,

$$
\mathrm{DS}=\left[\begin{array}{c}
10 \mathrm{~L} \\
100 \mathrm{kWh}
\end{array}\right]
$$

となる. つぎに便益を走行距離と暖房の二種類とし, 軽油 の全てが走行距離の便益へ, 電気の全てが暖房への便益へ 使用されるとして, 軽油の燃費が $21.2 \mathrm{~km} / \mathrm{L}$, 電気による暖 房が $10.8 \mathrm{MJ} / \mathrm{kWh}$ とすると,

$$
\mathrm{CDS}=\left[\begin{array}{cc}
21.2 \mathrm{~km} / \mathrm{L} & 0 \\
0 & 10.8 \mathrm{MJ} / \mathrm{kWh}
\end{array}\right]\left[\begin{array}{c}
10 \mathrm{~L} \\
100 \mathrm{kWh}
\end{array}\right]=\left[\begin{array}{c}
212 \mathrm{~km} \\
1,080 \mathrm{MJ}
\end{array}\right]
$$

となる.

ただし， $m=1$ の場合，たとえば走行距離 $[\mathrm{km}]$ という 一つの単位を持つエネルギー便益だけを対象とすれば，エ ネルギー収支比が熱量という一つの単位を取り扱ったよう に, 式 (2) の整合性が担保され, 便益比 $B_{P R}$ によって, バ イオ燃料生産を評価することがでさる。 また，式（2）にお いて, $m \geq 2$ の場合のように複数の便益を対象とする場合 には, それぞれの便益の単位が異なるため, 式 (2) の便益 比を用いて評価することができなくなるため, 便益変換係 数Cの要素に個別に変換係数を与えて対応する必要性が生 じる.

\section{統合便益比}

省エネ対策の導入に伴う快適性や機能性といった, 間接 的便益を評価するために, 多属性効用関数の概念にもとづ いて提案された便益の統合評価式（溝口ら 2008）がある. 多属性効用関数とは, 指標や重要度の異なる複数の評価項 目の值を, 人間の価值観を考慮して, 効用という一つの指 標で表した関数である. そこで, 一つの評価項目の值と充 
足度の関係を表す単属性効用関数を求め, 複数の評価項目 それぞれの単属性関数に重みを乗じて加算することによっ て決定する（溝口ら 2008）.

本論文では, 式 (2) の $m \geq 2$ の場合のように, 複数の便 益を対象とする場合に対応するために, 便益の統合評価式 の考え方にもとづいて, 単位の異なる便益 $B_{i}$ の值を, 充足 度関数 $U_{i}\left(B_{i}\right)$ によって充足度という単位で取り扱い, バ イオ燃料生産が導入される前の便益の充足度に対する重み $g_{i}$, バイオ燃料生産が導入された後の便益の充足度に対す る重み $h_{i}$ によって統合化を行った. 充足度関数とは, ある エネルギー便益の量が，利用者にとってどれだけ満足でき るかを定量的に表したものである（溝口ら 2008）。充足度 関数 $U_{i}\left(B_{i}\right)$ を単属性効用関数とみなすと, 複数の評価項 目を考慮し全体としての効用を求めるための多属性効用関 数（溝口ら 2007）は, 便益量と充足度の関係を表す複数の 単独性効用関数を求め, それらの単属性効用関数に重みを 乗じ，加算することにより決定することができる。

よって，バイオ燃料生産に投入したエネルギーによって 得られる多属性効用関数 $f_{\text {input }}$ は,

$$
f_{\text {input }}=\sum_{i=1}^{n} g_{i} U_{i}(\mathrm{CD} S)_{i}
$$

バイオ燃料生産で得られたエネルギーによって得られる 多属性効用関数 $f_{\text {output }}$ は,

$$
f_{\text {output }}=\sum_{i=1}^{n} h_{i} U_{i}\left(\mathrm{CD}^{\prime} S\right)_{i}
$$

となる.

ここで, 式 (3)（4）の試算例にあるような, 走行距離か 暖房かといった異なる便益を，今後の社会に対してどのよ うに取り入れ，最終的にどのように重み付けを行うかにつ いては, 総合的な政策に関わる意思決定者, あるいは意思 決定グループの主観的な判断が大きいと考えられる. たと えば，溝口ら（2007）は，住宅における省エネルギー対策 について，本論文の提案と同様に，意思決定者の主観的な 情報に基づいて決定される便益の統合式を提案している. 一方で，意思決定支援のための階層化分析法である AHP/ ANPのモデル利用では, 政策的な評価を行うために, それ ぞれの代替案が持つ物理的, 客観的な数値をもとに, 人間 の主観で代替案や評価項目に対して重み付けを行い, 総合 評価を行っている. よって, 本論文では, 主観的な重み付 けによって, 式（5）のそれぞれの便益に対する重み,

$$
\sum_{i=1}^{n} g_{i}=\sum_{i=1}^{n} h_{i}=1
$$

を決定することになる. したがって, 統合便益比 $I_{B P R}$ は,

$$
I_{B P R}=\frac{f_{\text {output }}}{f_{\text {input }}}=\frac{\sum_{i=1}^{n} h_{i} U_{i}\left(\mathrm{CD}^{\prime} S\right)_{i}}{\sum_{i=1}^{n} g_{i} U_{i}(\mathrm{CD} S)_{i}}, \sum_{i=1}^{n} g_{i}=\sum_{i=1}^{n} h_{i}=1
$$

と表すことができる.

なお，本論文では，バイオ燃料生産が導入された場合に， 導入される前と後では, どのように社会全体の便益が変化 するかを示すために，現在の社会需要に相当するそれぞれ の便益の重み付けを固定し,

$$
w_{i}=g_{i}=h_{i}
$$

として試算を行うこととした，一方で， $m=1$ の場合，つ まり式（2）で表される一つの便益を対象としたものは, 式 （8）に拈いて, 充足度関数の $U_{i}\left(B_{i}\right)$ が便益量 $B_{i}$ と比例関 係にある特殊なケースとして表すことができる.

\section{統合便益比の算出までの流れ}

エネルギー収支比，便益の変化量，統合便益比の算出の 流れを図 1 に示す。図 1 に示されるように, 本論文では, 対象となるバイオ燃料生産体系における投入エネルギー, 産出エネルギーの全てを抽出し, エネルギーとしての熱量 換算から得られた「エネルギー収支比」に加え, バイオ燃 料生産体系の導入に関与する意思決定者, あるいは意思決 定グループによる「統合便益比」の提案を行うものである.

意思決定者は, まず, 対象とするバイオ燃料生産体系が 導入される場合に, 社会的に影響を与える便益, たとえば 走行距離, 暖房などといった便益を抽出する. ここで, エ ネルギー便益が決定されれば, バイオ燃料生産体系の導入 による「便益の変化量」を求めることができる，つぎに， アンケート調査や回帰分析手法を利用し，できるだけ客観 的に便益に対する充足度関数の決定を行い, 単属性効用関 数として決定する. さらに, 個々の便益に対する重みを決 定し, 多属性効用関数の統合化によって, 統合便益比を算 出することができる. このように, エネルギ一便益の抽出, 便益の充足度関数の決定, 個々の便益に対する重みの決定 には，意思決定者の主観的な判断や，その重みが結果に反 映されることになる。

\section{統合便益比の試算}

\section{対象地域とエネルギー便益}

宇都宮市におけるエネルギー便益と, 宇都宮市の耕作放 棄地の水田圃場を対象として, 本論文で提案した統合便益 比の試算を行った. バイオ燃料の原料となる稲の収穫が, 年一回であることを考慮して，一年間のエネルギーの生産 と消費を試算の対象とした. 主なデータを表 1 , 表 2 に示す.

エネルギー便益は，バイオ燃料の輸送用燃料としての便 益である「走行距離」，および民生部門のなかでもエネル ギー消費が多い家庭用の「暖房」の二つとした（宇都宮市 2007）（表 2). ただし, 軽油はディーゼル車による走行距離 の便益へ, ガソリンとエタノールはハイブリッド車の走行 距離の便益へ，灯油は灯油の熱量分が暖房の便益へ変換さ れるとした. 蒸気は, 発電効率 $40 \%$ で電力に変換された後, 


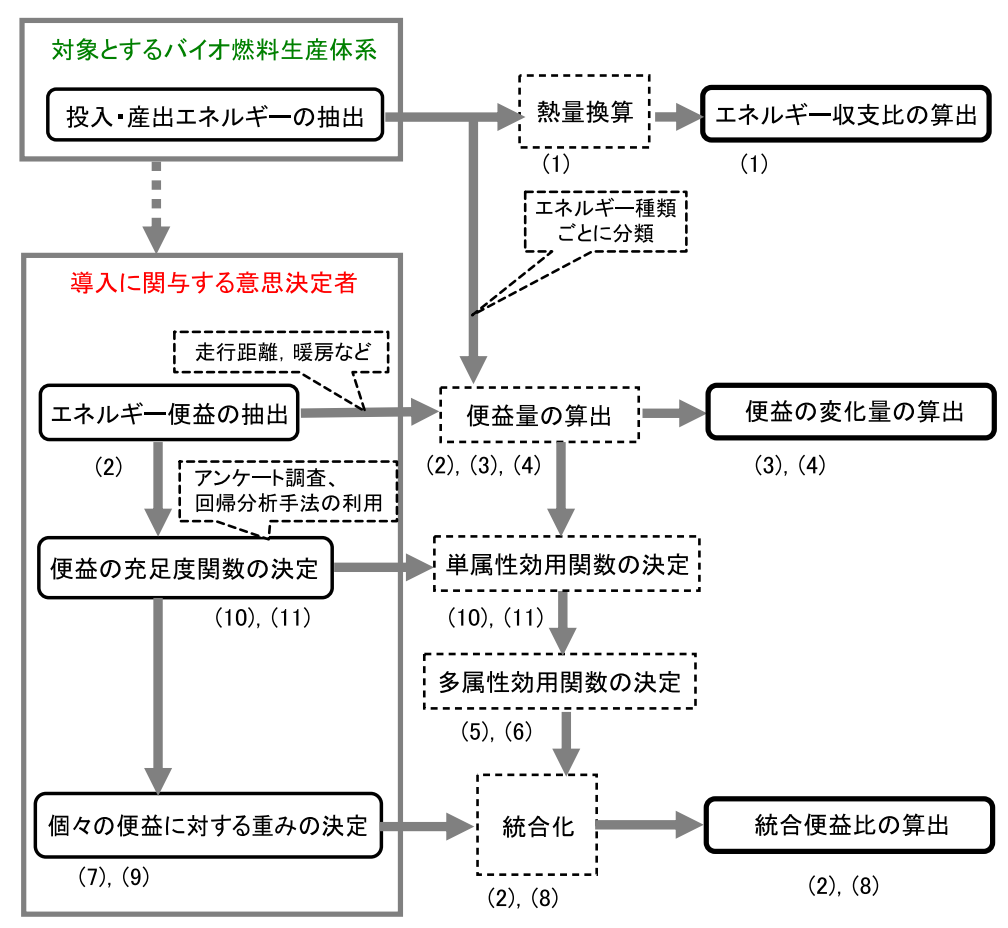

※「( )」は，対応する本文中の式番号を示す

図 1 エネルギー収支比, 便益の変化量, 統合便益比の算出の流れ

表 1 対象地域（宇都宮市）のデータ

\begin{tabular}{llll}
\hline \multicolumn{1}{c}{ 項目 } & \multicolumn{1}{c}{ 值 } & \multicolumn{1}{c}{ 引用文献など } \\
\hline 面積 & $416.84 \mathrm{~km}^{2}$ & 宇都宮市統計データバンク & 2005 \\
人口 & 510,063 人 & 宇都宮市統計データバンク & 2005 \\
世帯数 & 182,429 世帯 & 宇都宮市統計データバンク 2005 \\
耕作放棄地面積 & $333 \mathrm{ha}$ & 栃木県企画部統計課 2006 & \\
自動車保有台数 & 100,495 台 & 宇都宮市統計データバンク 2008 \\
自動車の年間走行距離 & $8,700 \mathrm{~km} /$ 年/台 & 国土交通省 2006 \\
総自動車の年間走行距離 & $874,306,500 \mathrm{~km} /$ 年 & ※上記のデータを用いた計算結果 \\
1 世帯の年間暖房熱量 & $10,420 \mathrm{MJ}$ & 日本エネルギー経済研究所 2008 \\
総世帯の年間暖房熱量 & $1,900 \mathrm{TJ} /$ 年 & ※上記のデータを用いた計算結果 \\
\hline
\end{tabular}

成績係数 3.0 のヒートポンプによって暖房の便益へ变換さ れるとした。

\section{試算対象となるバイオ燃料生産}

バイオ燃料生産は, 稲作からのエタノール生産を行う場 合のエネルギー収支の試算結果（佐賀ら 2007）を用いて, エタノールのみのエネルギー生産を行うバイオ燃料生産 (以下「エタノール生産」), およびエタノールと発電のエネ ルギー生産を行うバイオ燃料生産（以下「エタノール・電 力併産」）の二種類を対象とした. エタノール生産は, 稲を 生産し, 玄米からエタノールを生産するとともに, 稲わら と籾殼を加水分解により糖化させ, その糖化工程で副生さ れるリグニンをガス化発電させて, エタノール変換に必要 なエネルギーを補うものである.エタノール・電力併産は,
稲を生産し, 稲わらと籾殼をガス化発電させ，玄米からの エタノールを生産するために必要な電力と蒸気を賄い, 余 楼電力をエタノールとともに生産エネルギーとするもので ある. なお，投入エネルギーは全て直接エネルギーである.

\section{システム境界とエネルギーの流れ}

システム境界とエネルギー利用の流れを図 2 に示す。な お, 図 2 の上位には, エネルギーストックがあり, エネル ギーの種類ごとの生産 (上向き矢印) や投入 (下向き矢印) を示すとともに，それぞれの破線で囲まれたバイオマス生 産 (稲), エネルギー変換プラント, エネルギー消費のそれ ぞれのモジュールで構成される範囲がシステム境界とし た. また，エネルギー消費モジュールには，エネルギー便 益の走行距離に寄与するハイブリッド車とディーゼル車 
表 2 エネルギー種別ごとの走行距離と暖房の便益

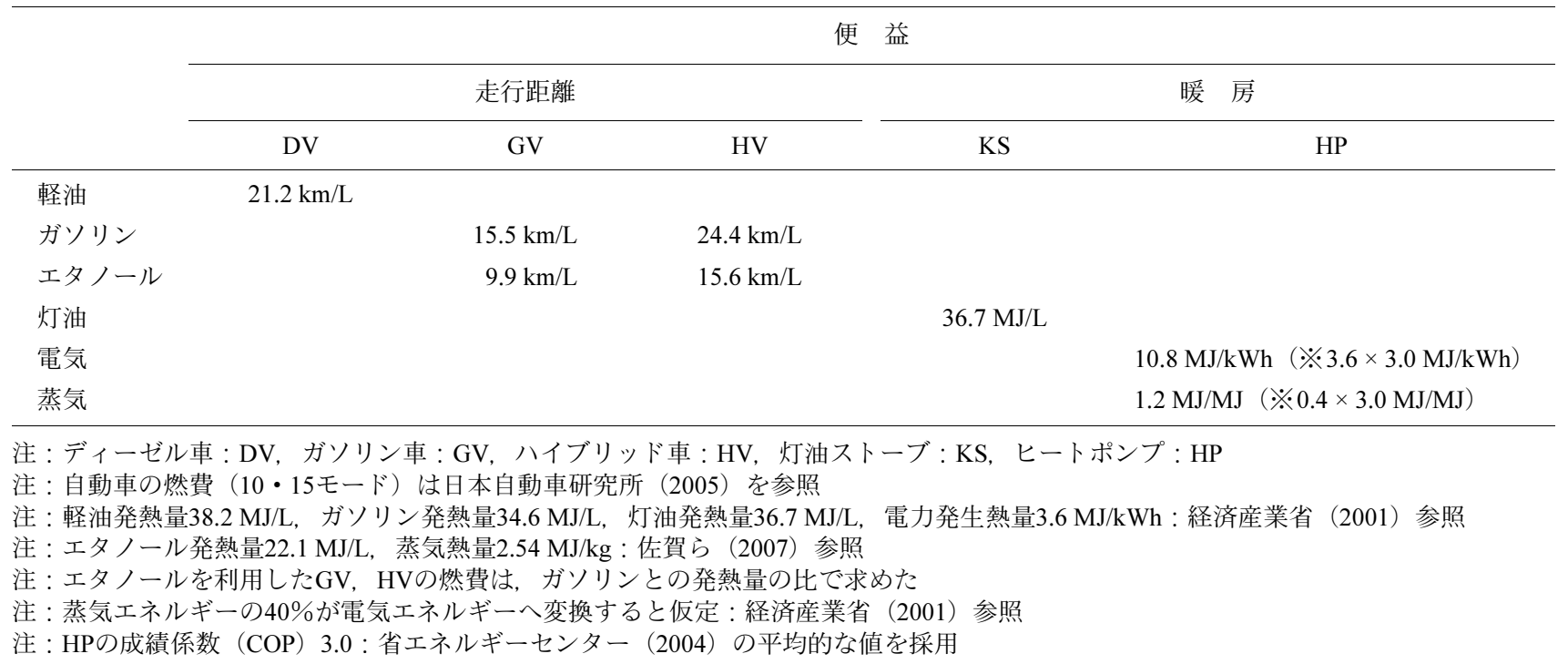
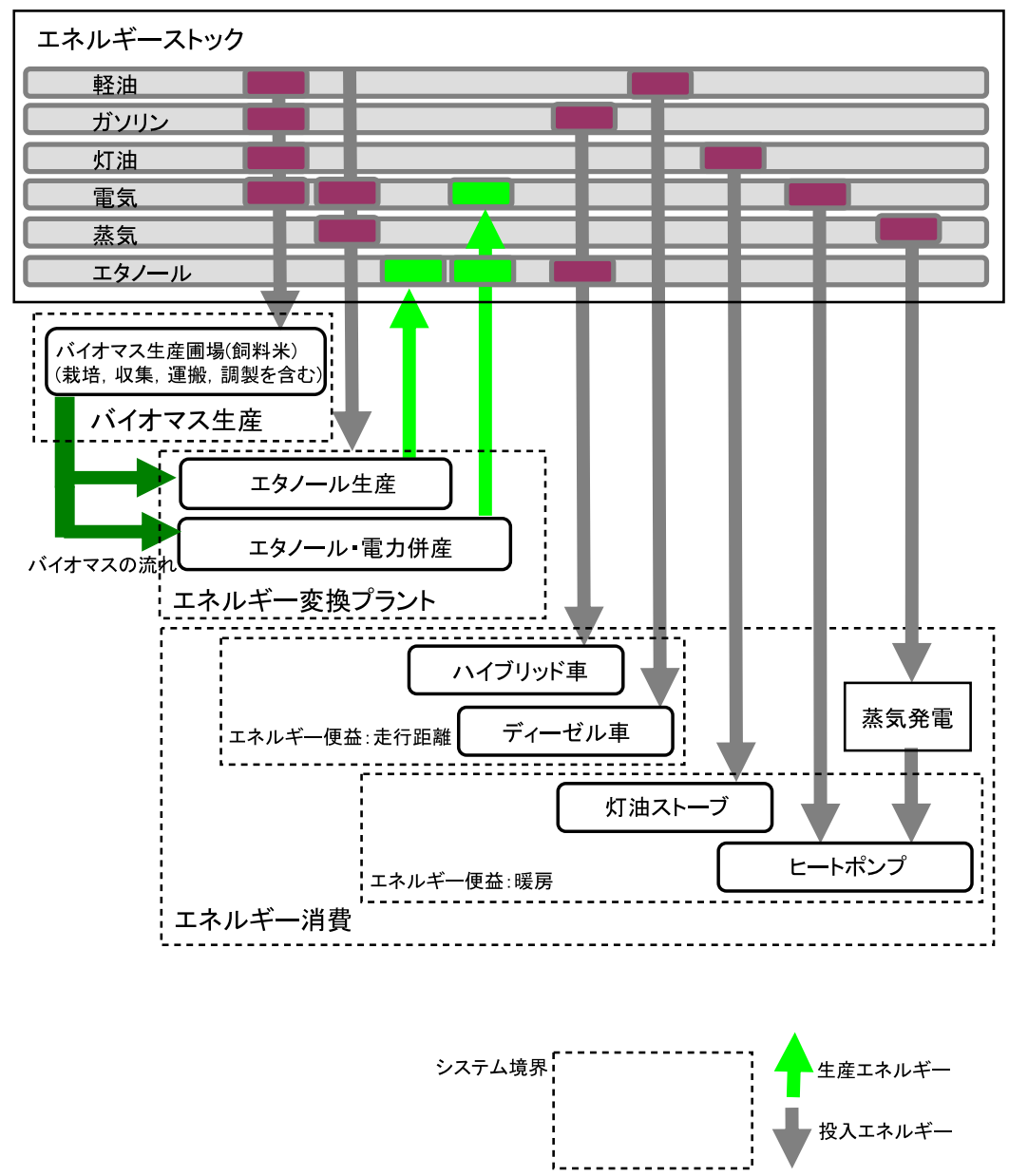

図 2 システム境界とエネルギー利用の流れ

を，エネルギー便益の暖房に寄与する灯油ストーブとヒー トポンプを用いた。

バイオマス生産による栽培, 収集, 運搬, 調製では, 軽 油, ガソリン, 灯油, 電気が投入される. 生産されたバイ
オマスは，エネルギー変換プラントへ流れる. エネルギー 変換プラントのエタノール生産では, 電気と蒸気が投入さ れ，エタノールが生産される（佐賀ら 2007）。また，エタ ノール・電力併産では, 内部で必要なエネルギーをバイオ 
マスで賄うため投入エネルギーは不要となり, 電気とエタ ノールが生産される（佐賀ら 2007）。エネルギー消費にお いて, ハイブリッド車はガソリンとエタノールを, ディー ゼル車は軽油を消費する。灯油ストーブは灯油を，ヒート ポンプは電気，および蒸気から発電した電気を消費する. 図 2 は, バイオマスの流れを示すとともに, これらのエネ ルギーの流れを, 上位にあるエネルギーストックを中心に， エネルギーの種類ごとの生産（上向き矢印）や投入（下向 き矢印) で示したものである. 最終的に, エネルギーストッ クの増減と, エネルギー消費への流れるエネルギーの種類 と量の関係から, 便益量の増減を検討する.

なお, 蒸気は, 温度, 圧力によってエネルギー量が違う が，本論文では同一熱量として取り扱った。 また，これら のエネルギーの流れにおけるライフサイクルのエネルギー は，直接エネルギーのみとし，製品の製造や廃棄に必要な 間接エネルギーは除外して取り扱った。 よって, 対象とし た二つのバイオ燃料生産体系における上流, 下流の産業は, システム境界の外とした。

\section{充足度関数}

充足度関数とは, あるエネルギー便益の量が, 利用者に とってどれだけ満足できるかを定量的に表したものであ り，最終的には対象者の感覚を表すファジィ理論における 非線形のメンバーシップ関数に近づくと考えられる. 本論 文では, 計算で関数值を求めやすい, 形状をパラメータに よって変化できる, といった利点から, 引用文献を参考に, シグモイド関数によって充足度関数を代替できると仮定し て（水沼 2002），エネルギー便益と充足度の関係を表すこと とした

シグモイド関数の傾斜の形状を決定する係数を $a$, 充足 度の最大值を $K$, 充足度の最大值となるエネルギー便益の 值を $b$ とし，つぎのように充足度関数 $U_{i}\left(B_{i}\right)$ を提案した.

$$
U_{i}(\mathrm{CDS})_{i}=\frac{K}{1+e^{-\frac{a}{b}\left\{(\mathrm{CDS})_{i}-\frac{b}{2}\right\}}}
$$

しかし, 式（10）はシグモイド関数によってこれらの充 足度を表現している。 これらの充足度関数は, 最終的に統 合便益比で表される.よって，Kの最大值はどのような值 でも, 分母分子の関係から比には影響を与えないため, 計 算しやすい数字として 100 を用いた. そこで, 充足度の最 大值 $K=100$ としたところ, 便益が 0 の時の充足度の值は 0 より大きく, 便益が最大值を示すときの充足度の值は 100 未満となる (表 3). そこで, 便益 $B_{i}$ の最大值 $B_{\text {imax }}$ では $U_{i}^{\prime}\left(B_{i}\right)$ の值が $K$, 最小值 $B_{\text {imin }}$ では $U_{i}^{\prime}\left(B_{i}\right)$ の值が 0 にな るように,

$$
U_{i}^{\prime}=\frac{K}{2}\left\{1+\left(U_{i}-\frac{K}{2}\right) \cdot \frac{1}{\frac{K}{2}-U_{i}\left(B_{\text {imin }}\right)}\right\}
$$

と補正し， $U_{i}\left(B_{i}\right)$ の代わりに $U_{i}^{\prime}\left(B_{i}\right)$ を用いることとした. 式（11）で示された充足度関数において，どの值を充足度 100\%とするかは, 本論文で提案した統合便益比を利用する 立場の判断に委齐られる。

\section{充足度関数の事例}

宇都宮市地球温暖化対策地域推進計画では, 2007 年度 (平成 19 年度) から 2012 年度（平成 24 年度）までの 6 年 間で, 2012 年度 (平成 24 年度) における温室効果ガス排 出量を, 2003 年度（平成 15 年度）に比べて, 市民 1 人又 は 1 事業者当たりで, 17\%削減することを目指している（宇 都宮市 2007). この温室効果ガス削減量 17\%というのは, 現 状では高い目標設定值であるため, 本論文での試算では, バイオ燃料生産の導入における目標值として十分であると 判断した.

そこで, 宇都宮市の 2005 年の耕作放棄地面積に相当する 約 333 haの水田圃場を利用した稲生産のバイオ燃料生産に ついて, 表 1 の総自動車の年間走行距離 874,306,500 km/ 年 の $17 \%$ である $148.6 \times 10^{6} \mathrm{~km} /$ 年を, 走行距離の充足度関数 の最大值 100 として評価を行った。 また，表 1 の総世帯の 年間暖房熱量 $1,900 \mathrm{TJ} /$ 年の $17 \%$ の $323 \mathrm{TJ} /$ 年を, 暖房の充 足度関数の最大值 $K=100$ として評価を行った.

これは, 年間総走行距離の $17 \%$ に相当するエネルギーが 得られた場合, また, 年間総暖房熱量の $17 \%$ に相当するエ ネルギー得られた場合，それぞれ充足度関数が $100 \%$ にな ることを示す。また，投入エネルギー，あるいは生産され たエネルギーが，その便益につながるエネルギーであり， かつ, その量が多ければ充足度が高くなる. 反対に, 便益 につながらないエネルギー, あるいは便益につながっても 量が少なければ, 充足度は低くなる。つまり, 式（8）の分 母はバイオ燃料生産に投入するエネルギーが本来もたらす 便益の満足度であり, 式（8）の分子は, バイオ燃料生産か ら得られたエネルギーがもたらす便益の満足度を示す。

なお, 式（8）における充足度の最大值 $K=100$, シグモ イド関数の傾斜の形状を決定する係数 $a$ は, 溝口ら (2008) が行った充足度関数（温熱快適性）のアンケート結果によ る同定結果を参考に，12 とした（表 3）（図3）.

なお，図 3 は，エネルギー便益のそれぞれ走行距離，暖 房に対する利用者の主観的な充足度を表す関数であり, 個 別の便益を表していることから, 単属性効用関数という位 置付けとなる. 充足度関数 (ここでの単属性効用関数) は, 現場において，たとえば，溝口ら（2008）のように，アン ケート調査等から回帰的に一つの方程式の係数を決定して いるように，できるだけ客観的な数值として決定する必要 があり，効用関数の構成法（測定法）にしたがって決定さ れるべきと考えられる，本論文ではこれまでに述べている ような評価式の提案に重点が置かれているため, 溝口ら （2008）の充足度関数に形状が近く, 変化が容易なシグモイ ド関数によって，それぞれの充足度関数を決定した。 
表 3 充足度を表すシグモイド関数のパラメータとエネルギー便益の関係

\begin{tabular}{clll}
\hline & & \multicolumn{2}{c}{ エネルギー便益 } \\
\cline { 3 - 4 } & & \multicolumn{1}{c}{ 走行距離 } & 暖 房 \\
\hline$K$ & 充足度 (最大值) & 100 & 100 \\
$c$ & シグモイド関数の傾斜の形状を決定する係数 & 12 & 12 \\
$b$ & 充足度 100 の時のエネルギー便益の值 & $148.6 \times 10^{6} \mathrm{~km} /$ 年 & $323 \mathrm{TJ} /$ 年 \\
& 便益が0の時の充足度 (誤差) & 0.247 & \\
& 便益が & \\
\hline
\end{tabular}
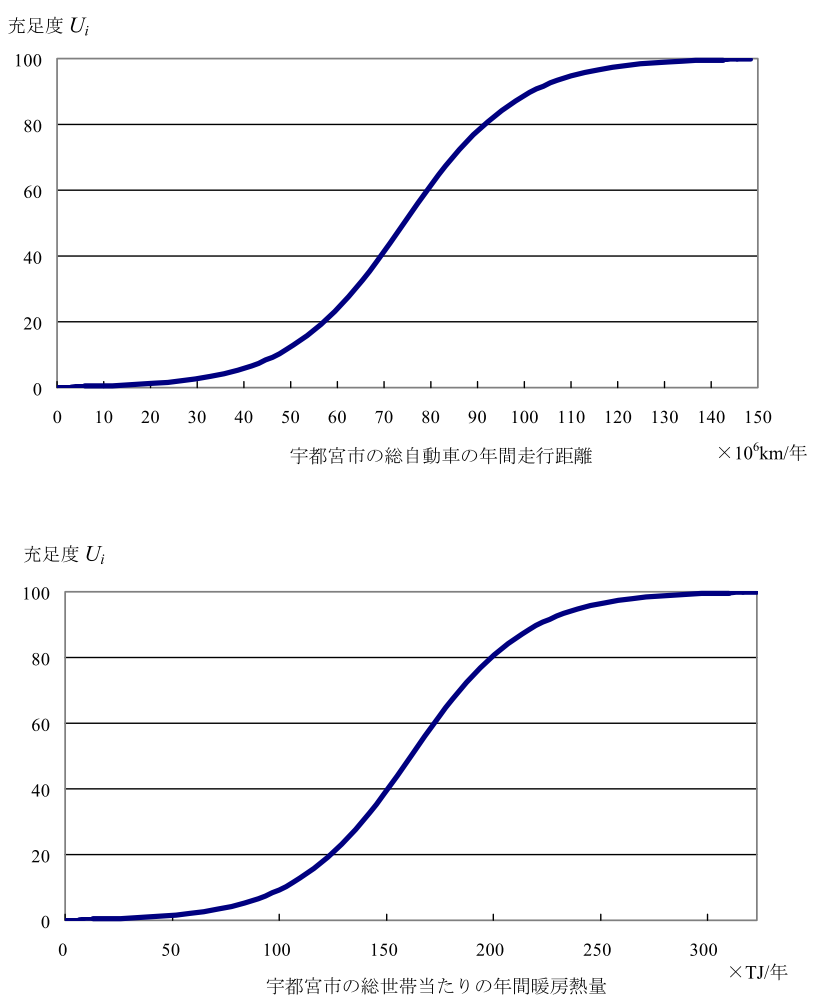

図 3 シグモイド関数を利用したエネルギー便益と しての充足度関数（単属性関数）

\section{結果と考察}

\section{エネルギー収支比と便益の変化量}

宇都宮市の耕作放棄地を対象とした，バイオ燃料生産に おける投入・生産エネルギーと便益の変化量の関係を表 4 に示す。エタノール生産では，バイオ燃料を生産するプラ ントに投入されるエネルギーが多いことから，投入エネル ギーのうち電気エネルギーが $1,140 \mathrm{kWh} / \mathrm{ha}$, 蒸気エネル ギーは $78,790 \mathrm{MJ} / \mathrm{ha}$ となった。 また, 投入の総熱量 214,100 MJ/ha と生産の総熱量 156,270 MJ/ha から, エネル ギ一収支比は 0.73 となった。 エネルギ一便益は，エタノー ルの生産に特化したバイオ燃料生産であるため, 走行距離 は 91,923 km/ha の増加, 暖房は 109,539 MJ/ha の減少となっ た. 一方で, エタノール・電力併産では, 投入の総熱量が $10,301 \mathrm{MJ} / \mathrm{ha}$ と小さく, 生産の総熱量 103,045 MJ/ha からエ
ネルギー収支比は 10.00 となった．また，エタノールのみ を生産エネルギーとして計上した場合でも，エネルギー収 支比は 7.68 となり，エネルギー効率の良い結果を示した。 しかし, 走行距離は $51,483 \mathrm{~km} / \mathrm{ha}$ の増加に留まった. なお, バイオ燃料のプラントから生産される電気エネルギーが 9,420 kWh/ha と大きかったため, これらの電気によるヒー トポンプの利用によって暖房は 97,761 MJ/ha の増加となっ た.

佐賀ら（2007）の結果より，エタノール生産では, バイ オマス（稲）からエタノールに特化した生産を行い, 外部 から不足するエネルギーを得ている. しかし, エタノール・ 電力併産では, 玄米のみをエタノール変換し, 稲わらや籾 殼をエタノール生産に必要なエネルギーとして利用し, 余った熱エネルギーで発電を行っている.よって, エタノー ル生産では, エタノールの生産量は多いが, 電気や蒸気を 加えた全体のエネルギー生産量は少なく, 逆に, エタノー ル・電力併産では, エタノール生産量は少ないが, 電気の 生産量が増えた結果となった。 したがって, エタノール生 産は, エネルギー収支比が悪く, 暖房の便益が減少するな かで, 単位面積当たりのエタノールの生産量が多いバイオ 燃料生産となった。一方で, エタノール・電力併産は, エ ネルギー効率が良く, 暖房の便益が増加するなかで, 単位 面積当たりのエタノールの生産量が少ないバイオ燃料生産 となった。よって，エネルギー収支比だけでなく，このよ うな便益量の変化を定量的に求めることによって，バイオ 燃料生産体系の社会的な便益の有用性を, 多面的に検討で きることが明らかとなった。

\section{充足度と統合便益収支比}

つぎに，バイオ燃料生産における便益量と充足度（表 5) から，エタノール生産の投入エネルギーによる走行距離の 充足度は 0.03 , 暖房の充足度は 0.71 , 生産エネルギーの走 行距離の充足度は 4.36 となった。 また, エタノール・電力 併産の投入エネルギーによる走行距離の充足度は 0.03 , 暖 房の充足度は 0.01 , 生産エネルギーの走行距離の充足度は 0.86 , 暖房の充足度は 0.62 となった。 これらの結果から, 宇都宮市の耕作放棄地面積に相当する 333 haの水田固場を 活用した稲生産からのバイオマス供給によるバイオ然料生 産が導入された場合, シグモイド関数による充足度関数 (範 囲：0〜 100）から，自動車の年間走行距離の $17 \%$ の 148.6 
表 4 バイオ燃料生産における投入・生産エネルギーと便益の変化量

○エタール生産

\begin{tabular}{|c|c|c|c|c|}
\hline & \multicolumn{2}{|c|}{ エネルギー } & \multicolumn{2}{|c|}{ エネルギー便益 } \\
\hline & 投入 & 生産 & 走行距離 & 暖房 \\
\hline 軽油 & $123 \mathrm{~L} / \mathrm{ha}$ & & (DV) $-2,608 \mathrm{~km} / \mathrm{ha}$ & \\
\hline ガソリン & $72 \mathrm{~L} / \mathrm{ha}$ & & (HV) $-1,757 \mathrm{~km} / \mathrm{ha}$ & \\
\hline 灯油 & $73 \mathrm{~L} / \mathrm{ha}$ & & & (KS) $-2,679 \mathrm{MJ} / \mathrm{ha}$ \\
\hline 電気 & $1,140 \mathrm{kWh} / \mathrm{ha}$ & & & (HP) $-12,312 \mathrm{MJ} / \mathrm{ha}$ \\
\hline 蒸気 & 78,790 MJ/ha & & & $(\mathrm{G} \rightarrow \mathrm{E} \rightarrow \mathrm{HP}) \quad-94,548 \mathrm{MJ} / \mathrm{ha}$ \\
\hline エタノール & & 7,070 L/ha & $(\mathrm{HV})+110,292 \mathrm{~km} / \mathrm{ha}$ & \\
\hline 合計 & $214,100 \mathrm{MJ} / \mathrm{ha}$ & $156,270 \mathrm{MJ} / \mathrm{ha}$ & 91,923 km/ha の増加 & 109,539 MJ/ha の減少 \\
\hline
\end{tabular}

エネルギー収支比：0.73

๑エタノール・電力併産

\begin{tabular}{|c|c|c|c|c|}
\hline & \multicolumn{2}{|c|}{ エネルギー } & \multicolumn{2}{|c|}{ エネルギー便益 } \\
\hline & 投入 & 生産 & 走行距離 & 暖房 \\
\hline 軽油 & $123 \mathrm{~L} / \mathrm{ha}$ & & (DV) $-2,608 \mathrm{~km} / \mathrm{ha}$ & \\
\hline ガソリン & $72 \mathrm{~L} / \mathrm{ha}$ & & $(\mathrm{HV})-1,757 \mathrm{~km} / \mathrm{ha}$ & \\
\hline 灯油 & $73 \mathrm{~L} / \mathrm{ha}$ & & & (KS) $-2,679 \mathrm{MJ} / \mathrm{ha}$ \\
\hline \multirow[t]{2}{*}{ 電気 } & $120 \mathrm{kWh} / \mathrm{ha}$ & $9,420 \mathrm{kWh} / \mathrm{ha}$ & & (HP) $-1,296 \mathrm{MJ} / \mathrm{ha}$ \\
\hline & & & & (HP) $+101,736 \mathrm{MJ} / \mathrm{ha}$ \\
\hline エタノール & & $3,580 \mathrm{~L} / \mathrm{ha}$ & $(\mathrm{HV})+55,848 \mathrm{~km} / \mathrm{ha}$ & \\
\hline \multirow[t]{2}{*}{ 合計 } & $10,301 \mathrm{MJ} / \mathrm{ha}$ & $103,045 \mathrm{MJ} / \mathrm{ha}$ & $51,483 \mathrm{~km} / \mathrm{ha}$ の増加 & 97,761 MJ/ha の増加 \\
\hline & & $\begin{array}{r}\text { エネル } \\
\text { エタノール生産 }\end{array}$ & $\begin{array}{l}\text { 比 : } 10.00 \\
\text { ネルギー収支比 : } 7.68\end{array}$ & \\
\hline
\end{tabular}

注 : HV : ハイブリッド車, DV : ディーゼル車, KS : 灯油ストーブ, HP : ヒートポンプ

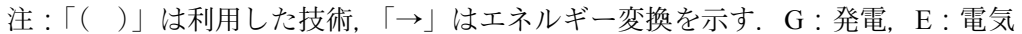

注：「十」は生産エネルギーによる便益量, 「一」は投入エネルギーによる便益量

表 5 バイオ燃料生産における便益量と充足度

\begin{tabular}{lllll}
\hline & & \multicolumn{1}{c}{ 便益量 } & 充足度 $($ 範囲 : $0 \sim 100)$ \\
\hline のエタノール生産 & & & \\
\hline 投入 & 走行距離 & $4.365 \mathrm{~km} / \mathrm{ha}$ & $1.5 \times 10^{6} \mathrm{~km}$ & 0.03 \\
& 暖房 & $109,539 \mathrm{MJ} / \mathrm{ha}$ & $36.5 \mathrm{TJ}$ & 0.71 \\
生産 & 走行距離 & $110,292 \mathrm{~km} / \mathrm{ha}$ & $36.7 \times 10^{6} \mathrm{~km}$ & 4.36 \\
\hline 一エタノール・電力併産 & & & \\
\hline 投入 & 走行距離 & $4.365 \mathrm{~km} / \mathrm{ha}$ & $1.5 \times 10^{6} \mathrm{~km}$ & 0.03 \\
& 暖房 & $3,975 \mathrm{MJ} / \mathrm{ha}$ & $1.3 \mathrm{TJ}$ & 0.01 \\
生産 & 走行距離 & $55,848 \mathrm{~km} / \mathrm{ha}$ & $18.6 \times 10^{6} \mathrm{~km}$ & 0.86 \\
& 暖房 & $101,736 \mathrm{MJ} / \mathrm{ha}$ & $33.9 \mathrm{TJ}$ & 0.62 \\
\hline
\end{tabular}

注 : 表1の耕作放棄地面積333 haを用いて計算

$\times 10^{6} \mathrm{~km} /$ 年に対する充足度は 4.36 以下, 総世帯の年間暖房 熱量の $17 \%$ の $323 \mathrm{TJ} /$ 年に対する充足度は 0.62 以下となっ た. さらに，エネルギー便益に重みの数值を加えた統合便 益比の変化を表 6 に示す. エタノール生産では, エネルギー 収支比が 0.73 であるにも関わらず，走行距離のウエイト $w_{1}$ を 1 とした場合, エタノール生産では統合便益比が
145.33, 走行距離のウエイト $w_{1}$ が 0.5 以上であれば, 統合 便益比が 5.89 以上となり, 走行距離の便益が大きくなる結 果となった. また，暖房のウエイト $w_{2}$ が 1 となると，エ タノール以外のエネルギーを生産していないことから, 統 合便益比が 0 となった. 一方で, エタノール・電力併産で は, 走行距離のウエイト $w_{1}$ を 1 とした場合, 統合便益比 
表 6 エネルギー便益に重みの数值を加えた統合便益比の変化

○エタノール生産

\begin{tabular}{|c|c|c|c|}
\hline \multicolumn{2}{|c|}{ 重み係数 $w_{1}+w_{2}=1$} & \multirow{2}{*}{ 統合便益比 $I_{B P R}$} & \multirow{2}{*}{ エネルギー収支比 $E_{P R}$} \\
\hline 走行距離 $w_{1}$ & 暖房 $w_{2}$ & & \\
\hline 1 & 0 & 145.33 & \multirow{11}{*}{0.73} \\
\hline 0.9 & 0.1 & 40.04 & \\
\hline 0.8 & 0.2 & 21.01 & \\
\hline 0.7 & 0.3 & 13.04 & \\
\hline 0.6 & 0.4 & 8.66 & \\
\hline 0.5 & 0.5 & 5.89 & \\
\hline 0.4 & 0.6 & 3.98 & \\
\hline 0.3 & 0.7 & 2.58 & \\
\hline 0.2 & 0.8 & 1.52 & \\
\hline 0.1 & 0.9 & 0.68 & \\
\hline 0 & 1 & 0.00 & \\
\hline \multicolumn{4}{|c|}{ のエタノール・電力併産 } \\
\hline \multicolumn{2}{|c|}{ 重み係数 $w_{1}+w_{2}=1$} & \multirow{2}{*}{ 統合便益比 $I_{B P R}$} & \multirow{2}{*}{ エネルギー収支比 $E_{P R}$} \\
\hline 走行距離 $w_{1}$ & 暖房 $w_{2}$ & & \\
\hline 1 & 0 & 28.67 & \multirow{11}{*}{ ※エタノール生産のみ 7.68} \\
\hline 0.9 & 0.1 & 29.86 & \\
\hline 0.8 & 0.2 & 31.23 & \\
\hline 0.7 & 0.3 & 32.83 & \\
\hline 0.6 & 0.4 & 34.73 & \\
\hline 0.5 & 0.5 & 37.00 & \\
\hline 0.4 & 0.6 & 39.78 & \\
\hline 0.3 & 0.7 & 43.25 & \\
\hline 0.2 & 0.8 & 47.71 & \\
\hline 0.1 & 0.9 & 53.67 & \\
\hline 0 & 1 & 62.00 & \\
\hline
\end{tabular}

が 28.67 となり，暖房のウエイト $w_{2}$ を大きくするにした がって, 統合便益比が増加した. 走行距離のウエイト $w_{1}$, 暖房のウエイト $w_{2}$ がともに 0.5 の場合, 統合便益比が 37.00 となり, エタノール・電力併産の統合便益比の高さを示した.

なお，表 6 の結果は，エタノール生産とエタノール・電 力生産の双方のケースについて, 便益として「走行距離」 と「暖房」を取り上げ, 重み $w_{1}, w_{2}\left(w_{1}+w_{2}=1\right)$ を変化 させて, 統合便益比の評価と検討を行った.つまり, 重み の值を一意に決めて結果を求めたものではなく, それぞれ の便益に対する重みの変化を与えることによって, どのよ うに統合便益比が変化するかを示し, 統合便益比の評価方 法について考察を行ったものである. よって, 宇都宮市に 対するエネルギー利用の絶対的な指標ということではな い. 実際に本手法を現場に適応する場合には, 本研究の評 価法をもとに, 様々な便益やエネルギーの利用を考慮する 必要があると考えられる.

これらの試算結果から, 本論文で提案された統合便益比 の評価式を用いることによって, 熱量換算だけでなく複数 のエネルギー便益の収支の観点から, バイオ燃料生産の評 価を, 数值を伴って行うことができると考えられる.さら に, 試算結果から, エネルギー収支比が 1 より少ない場合
でも，統合便益比が 1 を上回る場合があることが明らかと なった。 このように，エネルギ一収支比が 1 以下でも，統 合便益比が 1 以上であれば，それは導入する意味があると 判断できる可能性が残されていると考えられる. また逆に, エネルギー収支比が高くても, 統合便益比が悪ければ, 導 入を見送る必要がある場合が考えられる。したがって，工 ネルギー収支比に統合便益比を加えた評価によって，エネ ルギー収支比だけでなく, 社会全体のエネルギ一便益の増 減の観点から, 意思決定支援を行うことができる可能性が あると考えられる.

本論文では, バイオ燃料生産の導入といった社会的な対 象を取り扱い, そこでの評価法の提案, モデルの提案とい う点に論点を置いた。 したがって，バイオ燃料生産に関わ る広範囲なデータの収集のもとでのモデルの精度の検証 は, 現時点ではなされていない. 今後は, モデルの精度や 有効性の検証のために, バイオ燃料生産が導入された地域 でのこれまでの事例，あるいはこれから事例について，工 ネルギーの質と量の変化，それに伴う便益量の変化，およ び経済的な側面から, 検討を行うことが求められる.また, 今回の試算では, 式（11）と表 3 で表されるような, それ ぞれ一意に与えられたシグモイド関数の利用によって充足 
度関数を決定し，その結果から考察を行った. したがって， 統合便益比を利用してバイオ燃料生産の評価を行う場合に は，実際のエネルギー便益に対する社会的な充足度をアン ケート等によって調査し, シグモイド関数を同定するか, あるいは別の充足度関数を提案する必要がある.

\section{経済性の評価と今後の課題}

さらに，単位エネルギー当たりの価格を表す費用変換係 数行列 $\mathrm{M}(1 \times n)$ を用いると, 費用収支比 $A_{P R}$ は, 式 (2) にならって,

$$
A_{P R}=\frac{\mathrm{ME}^{\prime}}{\mathrm{ME}}=\frac{\mathrm{MD}^{\prime}}{\mathrm{MD}}
$$

となり，バイオ燃料生産の導入をエネルギーの市場価值で 換算することが可能である. なお, 式（12）の費用変換係 数行列 M は，エネルギーの費用（コスト）をエネルギー量 から求める変換係数であり, 費用変換係数行列 $\mathrm{M}(1 \times n)$ は, マトリックス（行列）で表されるため, 同じ变換行列 が用いられる，バイオ燃料生産の導入によって，投入され たエネルギーの市場価值と, 算出されたエネルギーの市場 価值と比べてどのように増減したかを判断するのは, バイ 才燃料生産の導入の判断として重要である. したがって, 市場価值と人々の充足度との関係からの統合便益比の検討 は，今後の課題であると考えられる.

\section{摘要}

1）バイオ燃料生産のエネルギー収支比による評価の問題 点を補うために，シグモイド関数を用いたエネルギー 便益の充足度関数，打よび複数の便益の統合化を行う 多属性効用関数にもとづいて, 統合便益比を提案した.

2）試算結果から, バイオ燃料生産の評価を, 熱量換算だ けでなく, 複数のエネルギー便益の収支の観点から評 価することによって, 社会全体のエネルギー便益の増 減を判断できる可能性が示された。

3）試算結果から, エネルギー収支比が 1 より少ない場合 でも, 統合便益比が 1 を上回る場合があり, エネルギー 収支比に統合便益比を加えた評価によって，エネル ギー収支比だけでなく，社会全体のエネルギー便益の 増減の観点から, 意思決定支援の可能性が示された。

\section{引用文献}

穴口明子・長谷部英司・深瀬壮健・大石 修 (1999) 行政評価を 考える一市民に分かりやすい評価システムを目指して, <http:/ /homepage3.nifty.com/npm/hyouka/ronbun/0.htm>, 2010年2月 21 日参照.

バイオマス・ニッポン総合戦略推進会議（2007）国産バイオ燃料 の大幅な生産拡大, <http://www.maff.go.jp/j/biomass/b_energy/ $\mathrm{pdf} /$ kakudai01.pdf $>， 2010$ 年4月 16 日参照.

CIGR (1999) CIGR Handbook of Agricultural Engineering, 5, Energy \&
Biomass Engineering, ASABE (USA), 13-21.

Dalgaard, T., U. Jørgensen, J. E. Olesen, E. S. Jensen and E. S. Kristensen (2006) Looking at biofuels and bioenergy, Science, 323(23), 1743.

経済産業省 (2006) 新・国家エネルギー戦略, <http://www.meti.go.jp/ press/20060531004/senryaku-houkokusho-set.pdf>, 2010年2月 8 日 参照.

経済産業省（2001）エネルギ一源別発熱量の改訂について，<http:// www.meti.go.jp/kohosys/press/0001414/2/0330kakuho2.pdf $>$, 2010 年 2 月 8 日参照.

国土交通省（2006）平成 19年度国土交通白書，自家用乗用車から の二酸化炭素排出削減に向けた課題, http://www.mlit.go.jp/ hakusyo/mlit/hakusho/h20/html/j1211100.html, 2010年4月 14 日参 照.

Pimentel, D. and T. W. Patzek (2005) Ethanol production using corn, switchgrass, and wood; Biodiesel production using soybean and sunflower, Natural Resource Research, 14(1): 65-76.

溝口奈穂・村上周三・伊香賀俊治・新谷圭右（2008）省エネ対策 がもたらす直接的／間接的便益の評価手法の開発, 日本建築 学会学術講演梗概集 (中国), 1219-1220.

溝口奈穂・村上周三・伊香賀俊治・新谷圭右（2007）住宅におけ る省エネルギー対策の直接的／間接的便益の評価手法の開 発，2007年度日本建築学会関東支部研究報告集，525-528.

水沼洋人（2002）満足化概念を考慮した多目的計画法によるクラ 又編成問題の一解法, 名城論叢, 3(3): 9-17.

日本エネルギー経済研究所（2008）「エネルギー・経済統計要覧」, 東京, $382 \mathrm{pp}$.

日本自動車研究所 (2005) 「JHFC 総合効率検討結果」報告書, 平成 18年3月, <http://www.jhfc.jp/data/report/2005/pdf/result_main.pdf>, 102,2010 年3月 17 日参照.

野村総合研究所（2007）バイオ燃料に関する報告, <http:// www.paj.gr.jp/paj_info/topics/2008/pdf/20080110-report.pdf>, 2010 年 2 月 8 日参照.

野口良造・齋藤高弘（2008）インベントリ分析による機械化水稲 生産のエネルギー消費量・効率の考察, 農業情報研究, 17(1): 20-30.

佐賀清崇・横山伸也・芋生憲司（2007）稲作からのバイオマスエ タノール生産システムのエネルギー収支分析, エネルギー資 源学会, 29(1): 30-35.

省エネルギーセンター（2004）平成 16年度省エネルギー技術普及 促進事業調査報告書, ヒートポンプの技術, <http://www. eccj.or.jp/diffusion/04/diff_07_06.html\#06>, 2010年4月17日参照.

総務省（2007）統計局車種別保有自動車数, <http://www.stat.go.jp/ data/nenkan/12.htm>, 2010年2月 12 日参照.

栃木県企画部統計課（2006）農林業経営体調査結果概要（確定值） 栃木県版, http://www.pref.tochigi.lg.jp/pref/toukei/toukei/resources/ $1182471236253 . p d f, 2010$ 年4月 14 日参照.

宇都宮市（2008）宇都宮市統計データバンク，総合統計，<http:// www2.city.utsunomiya. tochigi.jp/DataBank/main_2.htm>, 2010年 4月 14 日参照.

宇都宮市（2007）宇都宮市地球温暖化対策地域推進計画，<http:// www.city.utsunomiya.tochigi.jp/dbps_data/_material_/localhost/ kankyo/kankyoseisaku/onndannka/gaiyouban.pdf>，2010年4月 17 日参照.

山地憲治（2006）「エネルギー・環境・経済システム論」, 岩波書 店, 東京, $186 \mathrm{pp}$.

受付日 2010年 5 月 7 日 受理日 2010年10月 3 日 担当分野工学分野 


\title{
Method for Evaluating Biofuel Production Systems from the Viewpoint of Final Benefit Integration - Trial Calculations for Automobile Mileage and Household Heating in Utsunomiya City-
}

\author{
Ryozo Noguchi*1) and Mizuki Koyama ${ }^{2)}$ \\ 1) Graduate School of Life and Environmental Sciences, University of Tsukuba, 1-1-1 Tennodai, Tsukuba, Ibaraki 305-8572, Japan \\ 2) Graduate School of Agriculture, Utsunomiya University, 350 Mine, Utsunomiya, Tochigi 321-8505, Japan
}

\begin{abstract}
The integrated benefit payback ratio (IBPR) is proposed as a method for evaluating biofuel production systems. This is based on the theory of a sigmoid function expressing the degree of satisfaction for an energy benefit and a multiattribute utility function to integrate multiple benefits to make up for inadequacy of energy payback ratio (EPR). The total annual amounts of automobile mileage and household heating in Utsunomiya City were expressed as a satisfaction function. The IBPR and EPR were calculated for two biofuel (bio-ethanol) production systems utilizing biomass supplied as rice produced on abandoned paddy fields in Utsunomiya City. The total energy benefit provided to society by the biofuel production systems was able to be measured not only from the viewpoint of heat conversion but also as a multi-benefit ratio. Because an IBPR of $>1.0$ and an EPR of $<1.0$ coexisted in some trial calculations, it is clear that not only EPR but also IBPR can be used to support decisions to introduce biofuel production systems providing increasing or decreasing energy benefits to a society.
\end{abstract}

\section{Keywords}

benefit, biofuel, energy portfolio ratio, satisfaction

\footnotetext{
* Corresponding Author

E-mail: noguchi.ryozo.gm@u.tsukuba.ac.jp
} 